\title{
Pityriasis Rosea in a Woman and Her Husband - Case Report and Review of the Literature
}

\author{
Natalya Lemster Michal Neumark Arieh Ingber \\ Department of Dermatology and Venereology, Hadassah University Hospital, \\ Faculty of Medicine, Hebrew University, Jerusalem, Israel
}

\section{Key Words}

Pityriasis rosea $\cdot$ Familial $\cdot$ Human herpes virus $\cdot$ Herald patch

\begin{abstract}
Pityriasis rosea is an acute, self-limited papulosquamous dermatosis of the trunk and extremities. Many atypical forms of the disease have been reported in the literature [Ahmed et al.: Clin Exp Dermatol 2000;25:624-626; Imamura et al.: Dermatologica 1985;171:474-477]. It is rare to find pityriasis rosea in multiple family members (within a household) at the same time. There have been only 4 reported cases where a couple has contracted pityriasis rosea simultaneously [Miller et al.: Arch Derm Syphilol 1941;44:6668; Niles et al.: Arch Derm Syphilol 1940;41:264].
\end{abstract}

\section{Introduction}

The term pityriasis rosea (PR) was first used by Gibert in 1860 [1]. The name PR was chosen because the lesions are pink (rosea) scales (pityriasis). PR is a common acute, selflimited skin eruption that typically begins as a single thin oval scaly plaque on the trunk ('herald patch') and is typically asymptomatic. Within several days to 3 weeks the initial lesions are followed by the appearance of numerous similar-appearing smaller lesions located along the lines of cleavage of the trunk (a so-called Christmas tree pattern). The primary plaque of $\mathrm{PR}$, or herald patch, is seen in $50-90 \%$ of cases. It is normally well demarcated, 2-4 cm in diameter, oval or round, salmon colored, erythematous or hyperpigmented (especially in individuals with darker skin), and demonstrates a fine collarette scale just inside the periphery of the plaque [2]. Many atypical forms of the disease have been reported in the literature $[3,4]$. 


\begin{tabular}{c|l|l|l} 
Case Reports $\boldsymbol{h}$ & $\begin{array}{l}\text { Case Rep Dermatol 2010;2:135-139 } \\
\text { D01: } 10.1159 / 000319759\end{array}$ & Published online: August 6, 2010 & $\begin{array}{l}\text { ○ 2010 S. Karger AG, Basel } \\
\text { ISSN 1662-6567 } \\
\text { www.karger.com/cde }\end{array}$ \\
\hline
\end{tabular}

\section{Case Report}

We report on a 28 -year-old woman in the 38th week of her first pregnancy, otherwise healthy, who presented in our outpatient clinic. The patient's medical history included a cholecystectomy in 1999. The patient reported that the rash had appeared 10 days earlier. She complained on scaly patches with peripheral collarette scaling mostly over the upper trunk and thighs accompanied with light itching. The patient was treated with Aflumycin cream (prednisolone $0.5 \%$, gentamycin sulphate $0.1 \%$ ) without response before she came to our clinic. A few days later, a similar rash appeared on her husband's skin. He then came to our clinic with his wife on her next visit. Both patients did not have any prodromal symptoms. Drug exposure before skin eruption was excluded in both cases. Upon examination of the female patient, a skin rash consisting of oval-shaped salmon-colored patches and papules, up to $1.5 \mathrm{~cm}$ in diameter, surrounded by light white scales located on her neck, chest, thighs and upper limbs was noticed (fig. 1). A larger oval shaped lesion on the left thigh ('herald patch') had appeared a few days before the generalized rash showed.

Examination of her husband revealed a similar rash consisting of red-pink oval-shaped plaques surrounded by light scales localized on his neck and upper limbs (fig. 2).

Laboratory tests including blood count and liver function were within normal values. VDRL, TPHA, IgM-CMV, and IgG rubella were all negative. A biopsy from the husband's skin showed mild spongiosis and superficial perivascular mononuclear infiltrate with focal extravasated erythrocytes, compatible with PR (fig. 3). Biopsy from the woman's skin was not done. Clinical follow-up for both patients showed that the rash resolved without treatment after 4 weeks.

\section{Discussion}

Clinical diagnosis of PR in both patients was made by two different dermatologists. The diagnosis was confirmed according to published diagnostic criteria: peripheral collarette scaling with central clearance on at least two lesions. The biopsy of a typical lesion in the husband was compatible with PR.

The cause of pityriasis rosea is unknown. An association with human herpesvirus 6 and 7 (HHV-6 and HHV-7) has been reported but remains controversial. Numerous studies over the past 50 years have explored various pathogens as possible causes of PR. These pathogens included numerous bacteria, fungi, and, most notably, viruses. According to a study by Drago and colleagues $[5,6]$ most recent PR etiologic and pathogenetic studies have been focused on two ubiquitous HHVs, HHV-7 and HHV-6. Another study by Drago and colleagues [7] found such virions in lesional skin from pityriasis rosea patients. In this study, human herpes virus particles in various stages of morphogenesis were detected in 15 patients $(71 \%)$.

The infection agent of PR remains an open question. The incidence of occurrence of 2 or more cases in the same household is small compared with the total number of cases of PR. Niles and Klumpp [8], in their own review, reported 35 cases of PR in different households, 6 of them were couples ( 3 cases). Another report by Miller [9] presented 3 cases of PR in one family having been diagnosed within 6 weeks.

In conclusion, in our report we describe an additional case of pityriasis rosea occurring simultaneously in a couple. This case concerning a couple is an important one as it supports the infectious etiology hypothesis of the disease. 
Fig. 1. Oval-shaped salmon-colored patches up to $1.5 \mathrm{~cm}$ in diameter, surrounded by light white scales located on the neck of the female patient.

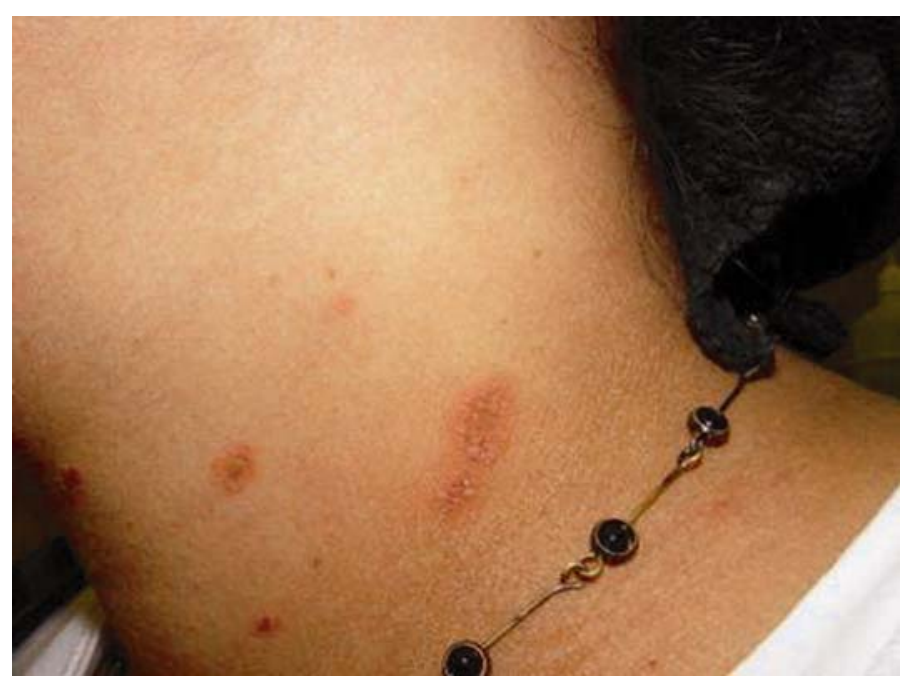

Fig. 2. Similar rash consisting of red-pink oval-shaped plaques surrounded by light scales localized on the upper limbs of the husband.

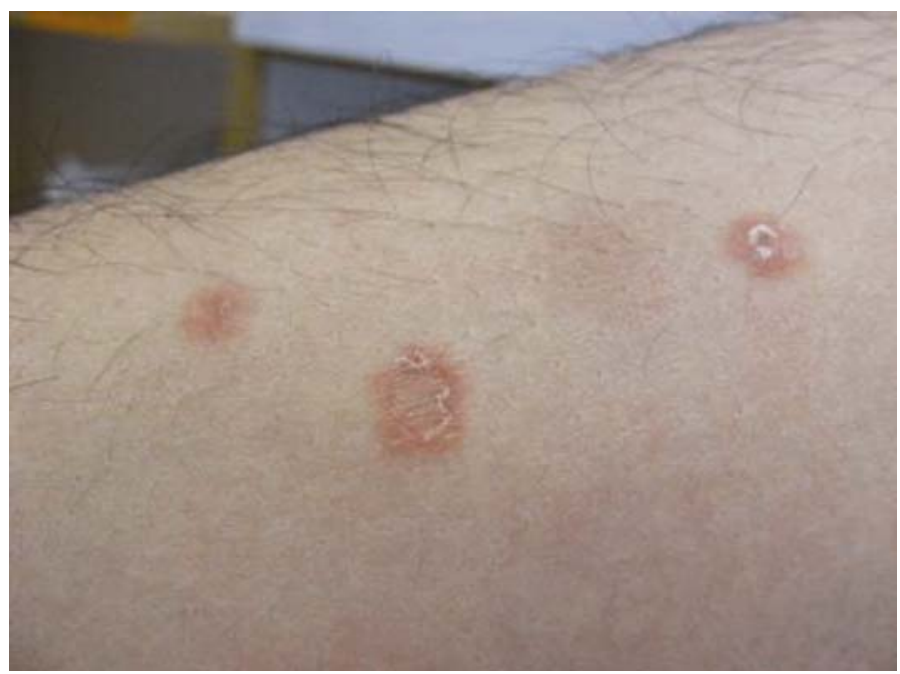




\begin{tabular}{c|l|l|l}
$\begin{array}{c}\text { Case Reports } \boldsymbol{h} \\
\text { Demmatolagly }\end{array}$ & $\begin{array}{l}\text { Case Rep Dermatol 2010;2:135-139 } \\
\text { D0I: 10.1159/000319759 }\end{array}$ & Published online: August 6, 2010 & $\begin{array}{l}\text { O 2010 S. Karger AG, Basel } \\
\text { ISSN 1662-6567 } \\
\text { www.karger.com/cde }\end{array}$ \\
\hline
\end{tabular}

Fig. 3. Biopsy from the husband's skin showing mild spongiosis and superficial perivascular mononuclear infiltrate with focal extravasated erythrocytes.

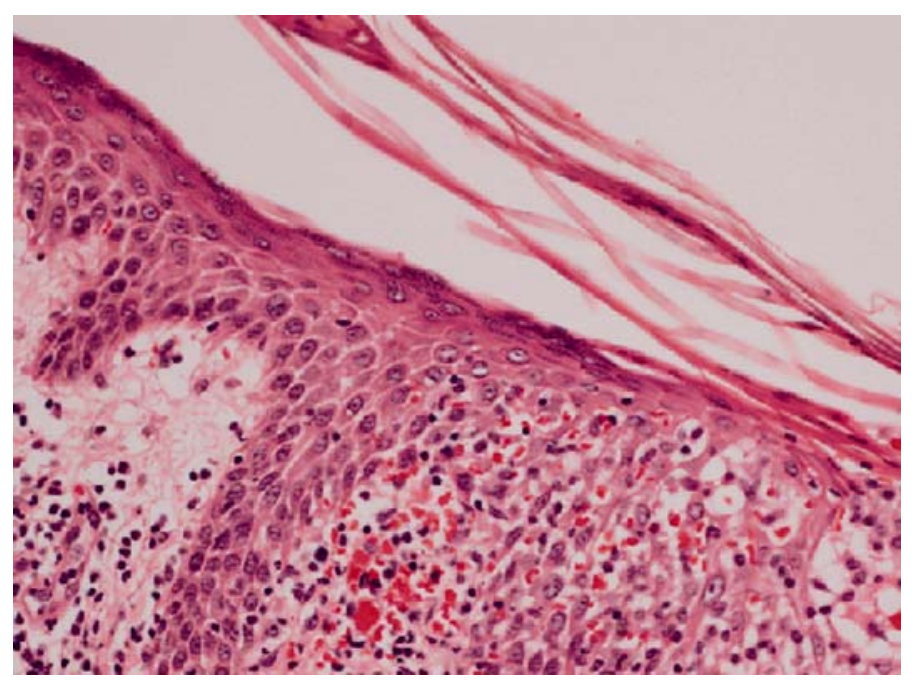




\section{References}

1 Gibert CM: Traite Pratique des Maladies de la Peau et de la Syphilis, 3rd ed. Paris, Plon, 1860.

2 Wolff K, Goldsmith L, Katz S, Gilchrest B, Paller A, Leffell D: Pityriasis rosea; in Fitzpatrick's Dermatology in General Medicine, 7th ed., vol. 1, McGraw-Hill, 2008, pp 362-366.

-3 Ahmed I, Charles-Holmes R: Localized pityriasis rosea. Clin Exp Dermatol 2000;25:624-626.

-4 Imamura S, Ozaki M, Horiguchi Y: Atypical pityriasis rosea. Dermatologica 1985;171:474-477.

5 Drago F, Ranieri E, Malaguti F, Losi E, Rebora A: Human herpesvirus 7 in pityriasis rosea. Lancet 1997;349:1367-1368.

-6 Drago F, Ranieri E, Malaguti F, Battifoglio ML, Losi E, Rebora A: Human herpesvirus 7 in patients with pityriasis rosea. Electron microscopy investigations and polymerase chain reaction in mononuclear cells, plasma and skin. Dermatology 1997;195:374-378.

7 Drago F, Malaguti F, Ranieri E, Losi E, Rebora A: Human herpes virus-like particles in pityriasis rosea lesions: an electron microscopy study. J Cutan Pathol 2002;29:359-361.

8 Niles HD, Klumpp MM: Pityriasis rosea: Review of the literature and report of two hundred and nineteen cases. Arch Derm Syphilol 1940;41:264.

9 Miller TH: Pityriasis rosea. Report of three cases in one family, with clinical variations in two of them. Arch Derm Syphilol 1941;44:66-68. 